\title{
Studi Deskriptif Persepsi Siswa Terhadap Layanan Orientasi Siswa Kelas X SMA Negeri 4 Yogyakarta
}

\author{
Sinta Budi Astuti \\ SMA N 3 Cilacap \\ J1. Kalimantan No. 14 Cilacap, Jawa Tengah, Indonesia \\ Email: shintabudiastuti@yahoo.co.id
}

\begin{abstract}
This study aims to describe the students' perception of the orientation services of class X SMA Negeri 4 Yogyakarta. This research is descriptive quantitative. The participants consisted 104 students of 10th grade at SMA Negeri 4 Yogyakarta selected by random sampling techniques. The instruments used in data collection are questionnaires. The obtained data of the students' perception of orientation services were analyzed using simple calculation by categorizing them into three criteria: good, moderate, poor. The results of the research showed that the students' perception of the orientation services of class X SMA Negeri 4 Yogyakarta are categorized as good, moderate, and poor, reaching the average percentage of each are $49 \%, 51 \%$, and $0 \%$, respectively. The results of this study can be used as consideration for the guidance and counseling teachers in developing orientation services in accordance with the students' needs and interests
\end{abstract}

Keyword: students' perception, orientation services, descriptive quantitative research

Penelitian ini bertujuan untuk mendeskripsikan persepsi siswa terhadap layanan orientasi pada siswa kelas X SMA Negeri 4 Yogyakarta. Penelitian ini merupakan penelitian deskriptif kuantitaif. Subjek penelitian berjumlah 104 siswa kelas X SMA Negeri 4 Yogyakarta yang diambil dengan teknik random sampling. Instrumen yang digunakan dalam pengumpulan data berupa angket. Data persepsi siswa terhadap layanan orientasi dianalisis menggunakan penghitungan sederhana dengan pengelompokan tiga kriteria yaitu baik, sedang, dan kurang. Hasil penelitian menunjukkan bahwa persepsi siswa terhadap layanan orientasi SMA Negeri 4 Yogyakarta diperolah data sebanyak 51 siswa (49 \%) berada pada kategori baik, sebanyak 53 siswa (51\%) berada pada kategori sedang, dan tidak ditemukan siswa yang memiliki persepsi terhadap layanan orientasi SMA Negeri 4 Yogyakarta yang berada pada kategori kurang. Hasil penelitian ini dapat dijadikan sebagai informasi bagi guru bimbingan dan konseling dalam mengembangkan layanan orientasi yang sesuai dengan kebutuhan dan minat siswa.

Kata kunci: persepsi siswa, layanan orientasi, penelitian deskriptif kuantitatif

\section{Pendahuluan}

Pendidikan memiliki peranan penting dalam mengembangkan kualitas sumber daya manusia. Melalui pendidikan, individu dapat belajar baik dari segi kognitif, afektif maupun psikomotor. Dalam Undang-undang Sistem Pendidikan Nasional no. 20 tahun 2003 pasal 3 dinyatakan bahwa Pendidikan Nasional berfungsi mengembangkan kemampuan dan membentuk watak serta peradaban bangsa yang bermartabat dalam rangka mencerdaskan kehidupan bangsa, bertujuan untuk berkembangnya potensi peserta didik agar menjadi manusia yang beriman dan bertakwa kepada Tuhan Yang Maha Esa, berakhlak mulia, sehat, berilmu, cakap, kreatif, mandiri, dan menjadi warga negara yang demokratis serta bertanggung jawab. Keberadaan guru bimbingan di sekolah belum dimanfaatkan secara optimal oleh siswa. Hampir semua siswa yang datang kepada guru pembimbing dikarenakan memiliki masalah, berkelahi, urusan akademik dan jarang sekali dengan sengaja untuk datang ke ruangan bimbingan dan konseling disekolah tersebut.

Keberadaan bimbingan dan konseling di sekolah dijadikan tempat untuk membantu memandirikan siswa agar setiap peserta didik mampu berkembang sesuai dengan tugas-tugas perkembangan yang ada. Hakikat bimbingan konseling di sekolah bertujuan untuk dapat mendampingi siswa dalam beberapa hal. Pertama, dalam perkembangan belajar di sekolah. Kedua, mengenal diri sendiri dan mengerti kemungkinankemungkinan yang terbuka. Sekarang maupun yang akan datang. Ketiga memberikan cita-cita dan tujuan dalam hidupserta menyusun rencana yang tepat untuk mencapai tujuan-tujuan itu. Keempat mengatasi masalah pribadi yang mengganggu belajar di sekolah. Empat peran di atas dapat 
efektifjika guru Bimbingan dan Konseling mampu melaksanakan layanan dengan baik.

Pada dunia bimbingan dan konseling tentu banyak sekali persepsi yang muncul tentang bagaimana peran guru bimbingan dan konseling dalam memberikan layanan, entah itu persepsi yang baik maupun persepsi buruk.Persepsi terjadi berdasarkan ada perhatian terhadap objek yang dibutuhkan.Persepsi positif berarti ada perhatian yang positif, persepsi negatif berarti adanya perhatian yang negatif terhadap guru bimbingandan konseling.

Persepsi baik positif maupun negatif, nanti juga akan mempengaruhi hasil dari kegiatan layanan bimbingan dan konseling. Dalam hal ini, jika siswa memiliki persepsi yang negatif, maka siswa akan enggan untuk berkonsultasi dengan guru pembimbing. Keengganan tersebut akan menghalangi ketersampaian informasi oleh siswa. Salah satu kegiatan yang dilakukan oleh pihak sekolah adalah Layanan orientasi adalah layanan berarti tatapan ke depan kearah dan tentang sesuatu yang baru. Hal ini sangat berkenan dengan berbagai kondisi yang ada, peristiwa yang terjadi dan kesempatan yang terbuka dalam kehidupan setiap orang. Salah satu yang membantu peserta didik untuk mengenal dan memahami keadaan dan situasi yang ada pada lingkungan sekolah yang baru dimasuki, agar peserta didik lebih familiar dengan sekolah sendiri,maka ia perlu mengetahui lebih jauh tentang berbagai fasilitas \& program-program yang ada di sekolah. Adapun upaya guru bimbingan dan konseling beserta guru-guru lainnya untuk memberikan pengenalan terhadap siswa siswi dalam masa orientasi inilah siswa mengenali guru guru disekolahnya sehingga siswa tidak berpersepsi terhadap guru bimbingan dan konseling di sekolah tersebut.

Orientasi siswa baru penting dilaksanakan karena merupakan kegiatan yang sangat strategis dalam pembinaan kesiswaan yang bertujuan mengantarkan siswa untuk beradaptasi di sekolah. Pada saat orientasi siswa baru, siswa belajar mengenal lingkungan sekolah yang baru, teman baru, guru baru, budaya belajar, tata tertib sekolah, dan lain-lain. Saat itu, siswa juga dibekalimateri kepribadian, keterampilan, dan ketangkasan.Jadi, kegiatan orientasi siswa baru diharapkan dapat membantu siswa dalam menyesuaikan diri dengan lingkungan sekolah secara cepat.

Berdasarkan hasil wawancara dengan dua orang guru bimbingan dan konseling di SMA Negeri
4 Yogyakarta pada tanggal 20 Agustus 2014 menunjukan bahwa layanan orientasi sudah berjalan dengan baik. Guru bimbingan dan konseling memberikan layanan Orientasi pada saat masa penerimaan siswa baru dengan memperkenalkan lingkungan sekolah, dan guru- guru di sekolah.

Salah satu kegiatan yang dilakukan oleh pihak sekolah adalah Layanan orientasi. Orientasi dapat diartikan tatapan ke depan kearah sesuatu yang baru. Hal ini sangat berkenan dengan berbagai kondisi yang ada, peristiwa yang terjadi dan kesempatan yang terbuka dalam kehidupan setiap orang. Salah satu yang membantu peserta didik untuk mengenal dan memahami keadaan dan situasi yang ada pada lingkungan sekolah yang baru dimasuki, agar peserta didik lebih familiar dengan sekolah sendiri,maka ia perlu mengetahui lebih jauh tentang berbagai fasilitas \& program yang ada di sekolah.

Berdasakan hasil wawancara dengan salah satu siswa di SMA Negeri 4 Yogyakarta siswa bernama nabila pada tanggal 22 Agustus 2014 yang menyatakan bahwa siswa disana sudah mengenal lingkungan di sekitar sekolah hanya siswa tersebut belum bisa menyesuaikan teman di sekitar sekolah tersebut, karena banyak siswa yang tidak mau mengenal dengan selain teman kelas.

Penelitian ini bertujuan untuk mengetahui persepsi siswa kelas $\mathrm{X}$ terhadap layanan orientasi di SMA Negeri 4 Yogyakarta. Melalui layanan orientasi, siswa dapat lebih mengenali dan memahami kondisi dan budaya yang ada di sekolah, sehingga layanan orientasi penting diberikan bagi siswa. Informasi mengenai persepsi siswa terhadap layanan orientasi penting untuk diteliti karena kemampuan siswa dalam menyesuaikan diri baik secara akademik maupun sosial di sekolah dapat dipengaruhi oleh pemberian layanan orientasi yang diberikan oleh guru bimbingan dan konseling pada siswa baru. Hasil penelitian ini dapat dijadikan sebagai bahan pertimbangan bagi para guru bimbingan dan konseling dalam memberikan dan mengembangkan layanan orientasi yang sesuai dengan kebutuhan siswa.

\section{Kajian Literature}

\section{Persepsi siswa}

Perspesi siswa terhadap layanan bimbingan dan konseling disekolah adalah aspek penting yang mempengaruhi keberhasilan layanan bimbingan dan konseling di sekolah. Persepsi siswa dapat mempengaruhi antusiasnya dalam mengiktuti 
PERSEPSI SISWA, LAYANAN ORIENTASI

layanan bimbingan dan konseling di sekolah. Menurut Daryanto (2010: 77) persepsi adalah proses yang menyangkut pesan masuk atau informasi ke dalam otak manusia. Melalui persepsi manusia terus menerus mengadakan hubugan dengan lingkungan. Hubungan ini dilakukan lewat indera, yaitu indera penglihatan, pendengaran, peraba, perasa, dan penciuman.

Desmita (2010:216) mengemukakan bahwa "persepsi suatu proses penggunaan pengetahuan yang telah dimiliki untuk memperoleh dan menginterprestasikan stimulus (rangsangan) yang diterima oleh sistem pada indera manusia". Jadi persepsi menyangkut hubungan manusia dengan lingkungan menggunakan pengetahuan yang dimiliki. Persepsi merupakan suatu proses hubungan manusia dengan lingkungan yang melibatkan tahapan-tahapan yang saling terintegrasi satu sama lain, yaitu berupa proses menangkap stimulus (rangsang), kognitif, dan upaya menginterpretasi. Sehingga penelitian ini diharapkan dapat memberikan masukan positif agar siswa memiliki gambaran atau penilaian tentang pelaksanaan layanan orientasi dan akhir terbentuk suatu sikap yang lebih kooperatif.

Walgito (2010: 101) menjelaskan sejumlahfaktor yang berperan dalam persepsi, meliputi objek yang dipersepsi, alat indera, syaraf dan pusat susunan syaraf dan perhatian. Parrek dalam Sobur (1996: 18) menjelaskan bahwa proses persepsi meliputiproses menerima rangsangan, proses menyeleksi rangsangan, proses pengorganisasian, proses penafsiran, proses pengecekan, dan proses reaksi.

Berdasarkan faktor dan proses persepsi maka proses persepsi merupakan bagian dari keseluruhan proses yang mengahasilkan tanggapan (pembentukan kesan) setelah rangsangan diterapkan kepada manusia. Tanggapan dari siswa bagaimana persepsi siswa terhadap layanan orientasi di sekolah tersebut.

\section{Layanan Orientasi}

Layanan orientasi merupakan salah satu jenis layanan dalam bimbingan dan konseling guna membantu siswa untuk mampu menyesuikan diri secara akademik dan sosial di sekolah. Menurut Yusuf (2012:27) Orientasi berarti tahapan ke depan kearah dan tentang sesuatu yang baru." Hal ini sangat penting berkenaan dengan berbagai kondisi yang ada, peristiwa yang terjadi dan kesempatan yang terbuka dalam kehidupan setiap orang. Kondisi yang baru yang terbuka tidak boleh dibiarkan berlalu begitu saja, tanpa makna dan guna, melainkan perlu ditangkap, ditatap, dipahami, dimaknai, disikapi, dan bahkan diberikan perlakuan agar kondisi, peristiwa dan kesempatan itu berguna dan membawa kesejahteraan dan kebahagian.

Prayitno (2008:255) "Layanan orientasi yaitu layanan bimbingan yang dilakukan untuk memperkenalkan siswa baru dan atau seseorang terhadap lingkungan yang baru dimasuki". Pemberian layanan ini betolak dari anggapan bahwa memasuki lingkungan baru bukanlah hal yang selalu dapat dengan mudah dan menyenangkan bagi setiap orang, ibarat seseorang baru pertama kali datang ke sebuah kota besar. Demikian juga bagi siswa baru di sekolah dan bagi orang yang baru masuk di dunia kerja, mereka belum tahu banyak mengenal tentang lingkungan yang baru.

Berdasarkan beberapa pengertian yang telah diuraikan diatas bahwa layanan orientasi suatu proses layanan bimbingan dan Konseling yang memberikan pengaruh besar agar peserta didik dapat mengenal suasana baru dan menyesuaikan terhadap lingkungan di sekolah tersebut.

Menurut Yusuf (2012:30) Layanan orientasi berupaya mengantarkan individu untuk memasuki seuasana atau lingkungan baru. Melalui layanan ini individu mempraktikan berbagai kesempatan untuk memahami dan mampu melakukan kontak secara konstruktif dengan berbagai elemen suasana baru tersebut. Lebih jauh, individu mampu menyesuaikan diri dan atau mendapatkan manfaat tertentu dari berbagai sumber yang ada pada suasana atau lingkungan baru tersebut

Menurut Sukardi (2008: 61) materi layanan orientasi dapat berupa pengenalan lingkungan dan fasilitas sekolah, peraturan dan hak-hak serta kewajiban siswa, organisasi dan wadah-wadah yang dapat membantu meningkatkan hubungan sosial siswa. Kurikulum dengan seluruh aspek-aspeknya, dan Peranan kegiatan bimbingan karir. berdasar pada materi layanan orientasi, yang dikembangkan oleh Sukardi (2008) maka dalam penggalian data tentang persepsi siswa terhadap layanan orientasi melalui engket, kisi-kisi pertanyan angket disusun beradasar pada materi layanan orientasi tersebut.

\section{Metode Penelitian}

Jenis penelitian yang digunakan dalam penelitian ini adalah jenis penelitian deskriptif kuantitatif.Lokasi penelitiaan di SMA Negeri 4 
Yogyakarta jl Magelang Karangwaru Lor, Tegalrejo, Yogyakarta. Populasi penelitian sebanyak 260 siwa dengan mengambil sampel sebanyak 40 $\%$ yaitu berjumlah 104 melalui teknik pengambilan sampling random sampling. Variabel dalam penelitian ini adalah persepsi siswa terhadap kinerja guru bimbingan dan konseling yang bersertifikasi. Instrumen yang digunakan dalam penelitian ini berupa angket. Analisis data yang dilakukan melalui penghitungan sederhana dengan pengelompokan kriteria. Kriteria yang digunakan adalah kurang, sedang dan baik.

\section{Hasil Peneltian dan Pembahasan}

Analisis data yang dilakuakn peneliti adalah berdasarkan data yangdiperoleh dari penelitian lewat pengisian angket persepsi siswa terhadap layanan orientasi pada siswa kelas X SMA Negeri 4 Yogyakarta.Angket tersebut memliliki jumlah item sebanyak 52 pernyataan dengan kriteria skor 14.Skor 4 adalah skor maksimal dari persepsi siswa terhadap layanan orientasi pada siswa kelas X SMA Negeri 4 Yogyakarta.Persepsi siswa teradap layanan orientasi dilihat dari persepsi siswa terhadap aspek pengenalan dan lingkungan fasilitas sekolah, peraturan dan hak-hak serta kewajiban siswa, organisasi dan wadah-wadah yang dapat membantu dan meningkatkan hubungan sosial siswa, kurikulum dengan seluruh aspek-aspeknya serta peranan kegiatan bimbingan karir yang sudah diberikan kepada siswa. Hasil data yang diperoleh dari penyebaran angket terhadap 104 siswa diperoleh dapat dilihat pada Tabel 1.

Tabel 1

Distribusi Kategorisasi Hasil Perhitungan PersepsiSiswa Terhadap Layanan Orientasi

\begin{tabular}{ccccc}
\hline No & $\begin{array}{c}\text { Interval } \\
\text { Skor }\end{array}$ & Frekuensi & $\%$ & Kriteria \\
\hline 1 & $156-$ & 51 & $49 \%$ & Baik \\
& 208 & & & \\
2 & $105-$ & 53 & $51 \%$ & Sedang \\
& 155 & & & \\
3 & $52-104$ & 0 & $0 \%$ & Kurang \\
& Total & 104 & $100 \%$ & - \\
\hline
\end{tabular}

Persepsi siswa terhadap layanan orientasi pada siswa kelas X SMA Negeri 4 Yogyakarta dilihat dari aspek pengenalan lingkungandan fasilitas sekolah, peraturan dan hak-hak serta kewajiban siswa, organisasi dan wadah-wadah yang dapat membantu dan meningkatkan hubungan sosial siswa, kurikulum dengan seluruh aspek-aspeknya, peranan kegiatan bimbingan karir, kategori persepsi siswa yang paling banyak masuk dalam kategorisedang.

Persepsi siswa terhadap layanan orientasi jika dilihat dari aspek-aspek yang terdapat dalam layanan orientasi yang meliputi aspek peranan kegiatan bimbingan karier, aspek peraturan dan hakhak serta kewajiban siswa, aspek organisan dan wadah yang dapat membantu hubungan siswa, aspek kurikulum dan seluruh aspeknya, dan aspek pengenalan lingkungan dan fasilitas sekolah, diperoleh data sebagai berikut:

1. Persiepsi siswa terhadap layanan orientasi pada aspek pengenalan dan lingkungan fasilitas sekolah dapat dilihat pada Tabel 2.

Tabel 2

Distribusi Kategorisasi dan Tingkat HasilPengenalan Lingkungan dan Fasilitas Sekolah

\begin{tabular}{ccccc}
\hline No & $\begin{array}{c}\text { Interval } \\
\text { Skor }\end{array}$ & Frekuensi & $\%$ & Kriteria \\
\hline 1 & $30-40$ & 73 & $67 \%$ & Baik \\
2 & $21-29$ & 34 & $33 \%$ & Sedang \\
3 & $10-20$ & 0 & $0 \%$ & Kurang \\
& Total & 104 & - & - \\
\hline
\end{tabular}

2. Persepsi siswa terhadap layanan orientasi pada aspek peraturan hak dan kewajiban siswa dapat dilihat pada tabel 3 .

Tabel 3

Distribusi Kategorisasi dan TingkatHasilPeraturan dan Hak Kewajiban Siswa

\begin{tabular}{ccccc}
\hline No & $\begin{array}{c}\text { Interval } \\
\text { Skor }\end{array}$ & Frekuensi & $\%$ & Kriteria \\
\hline 1 & $30-40$ & 59 & $57 \%$ & Baik \\
2 & $21-29$ & 45 & $43 \%$ & Sedang \\
3 & $10-20$ & 0 & $0 \%$ & Kurang \\
& Total & 104 & $100 \%$ & - \\
\hline
\end{tabular}

3. Persepsi siswa terhadap layanan orientasi pada aspek wadah-wadah yang dapat membantu dan meningkatkan hubungan sosial siswa dapat dilihat pada Tabel 4. 
PERSEPSI SISWA, LAYANAN ORIENTASI

Tabel 4

Distribusi Kategorisasi dan Tingkat Hasil Penilain Organisasi dan Wadah yang Dapat Membantu Hubungan Siswa

\begin{tabular}{ccccc}
\hline No & $\begin{array}{c}\text { Interval } \\
\text { Skor }\end{array}$ & Frekuensi & $\%$ & Kriteria \\
\hline 1 & $30-40$ & 64 & $62 \%$ & Baik \\
2 & $21-29$ & 40 & $38 \%$ & Sedang \\
3 & $10-20$ & 0 & $0 \%$ & Kurang \\
& Total & 104 & $100 \%$ & - \\
\hline
\end{tabular}

4. Persepsi siswa terhadap layanan orientasi pada aspek kurikulum dapat dilihat pada Tabel 5.

Tabel 5

Distribusi AspekKurikulum denganSeluruh Aspek-aspeknya

\begin{tabular}{cccc}
\hline $\begin{array}{c}\text { Interval } \\
\text { Skor }\end{array}$ & Frekuensi & $\%$ & Kriteria \\
\hline $33-44$ & 37 & $36 \%$ & Baik \\
$23-33$ & 67 & $64 \%$ & Sedang \\
$11-22$ & 0 & $0 \%$ & Kurang \\
Total & 104 & $100 \%$ & - \\
\hline
\end{tabular}

5. Persepsi siswa terhadap layanan orientasi pada aspek peranan kegiatan dapat dilihat pada Tabel 6.

Tabel 6

Distribusi Kategorisasi dan Peranan Kegiatan Bimbingan Karir

\begin{tabular}{ccccc}
\hline No & $\begin{array}{c}\text { Interval } \\
\text { Skor }\end{array}$ & Frekuensi & $\%$ & Kriteria \\
\hline 1 & $30-40$ & 34 & $33 \%$ & Baik \\
2 & $21-29$ & 68 & $65 \%$ & Sedang \\
3 & $10-20$ & 2 & $2 \%$ & Kurang \\
& Total & 104 & $100 \%$ & - \\
\hline
\end{tabular}

Berdasarkan hasil analisis secara keseluruhan persepsi siswa terhadap layanan orientasi di SMA Negeri 4 Yogyakarta dalam kategori sedang. Dinyatakan sedang, dilihat dari keseluruhan aspek layanan orientasi. Sejumlah aspek layanan orientasi tersebut adalah aspek tersebut adalah aspek pengenalan lingkungan dan fasilitas sekolah,Peraturan dan hak-hak serta kewajiban siswa, organisasi dan wadah yang dapat membantu hubungan siswa, kurikulum dan aspeknya, dan peranan bimbingan karir. Jika dilihat dari masingmasing aspek dapat dijabarkan seperti berikut:

1. Aspek pengenalan lingkungan dan fasilitas sekolah

Aspek pengenalan lingkungan dan fasilitas sekolahpada layanan orientasisiswa SMA Negeri 4 Yogyakarta masuk dalam kategori baik.Untuk data lebih lanjut dapat disajikan data sebagai berikut:bahwa siswa memiliki (67\%) terhadap layanan orientasi di SMA Negeri 4 Yogyakarta.

2. Aspek Peraturan dan hak-hak serta kewajiban siswa

Aspek Peraturan dan hak-hak serta kewajiban siswapada layanan orientasi siswa SMA Negeri 4 Yogyakarta masuk dalam kategori baik. Untuk data lebih lanjut dapat disajikan data sebagai berikut: bahwa siswa memiliki $59(57 \%)$ terhadap layanan orientasi di SMA Negeri 4 Yogyakarta.

3. Aspek organisan dan wadah yang dapat membantu hubungan siswa

Aspek organisan dan wadah yang dapat membantu hubungan siswa pada layanan orientasi siswa SMA Negeri 4 Yogyakarta masuk dalam kategori baik. Untuk data lebih lanjut dapat disajikan data sebagai berikut:bahwa siswa memiliki $59 \quad(57 \%)$ terhadap layanan orientasi di SMA Negeri 4 Yogyakarta.

4. Aspek kurikulum dan seluruh aspeknya

Aspek organisan dan wadah yang dapat membantu hubungan siswa pada layanan orientasi siswa SMA Negeri 4 Yogyakarta masuk dalam kategori sedang. Untuk data lebih lanjut dapat disajikan data sebagai berikut:bahwa siswa memiliki $67 \quad(64 \%)$ terhadap layanan orientasi di SMA Negeri 4 Yogyakarta.Hal tersebut dikarenakan belum adanya sosialisasi siswa terkait dengan kurikulum yang ada di sekolah.

5. Aspek peranan kegiatan bimbingan karier

Aspek peranan kegiatan bimbingan karierpada layanan orientasi siswa SMA Negeri 4 Yogyakarta masuk dalam kategori sedang. Untuk data lebih lanjut dapat disajikan data sebagai berikut:bahwa siswa memiliki 68 $(65 \%)$ terhadap layanan orientasidi SMA Negeri 4 Yogyakarta.Hal tersebut dikarenakan siswa belum mengetahui langkah dalam 
menyalurkan bakat, sehingga pandangan karir ke depan belum tercapai dengan baik.

\section{Simpulan}

Berdasarkan hasil yang diperoleh dari analisis data dan pembahasan, maka dapat disimpulkan bahwa persepsi siswa terhadap layanan orientasipada siswa kelas $\mathrm{X}$ SMA Ngeri 4 Yogyakarta dalam kategori sedang. Layanan orientasi tersebut dilihat dari aspek peraturan dan hak-hak serta kewajiban siswa, organisasi dan wadah yang dapat membantu hubungan siswa, kurikulum dan aspeknya, dan peranan bimbingan karir. Hasil penelitian ini dapat dijadikan sebagai informasi bagi guru bimbingan dan konseling dalam mengembangkan layanan orientasi yang sesuai dengan kebutuhan dan minat siswa

\section{Referensi}

Daryanto. (2010). Belajar dan Mengejar. Bandung: Ranawidya.

Desmita. (2010). Psikologi Perkembangan Peserta Didik. Bandung: Remaja Roskadarya.

Prayitno dan Amti, Erman. (2004). Dasar-dasar Bimbingan dan Konseling Jakarta: Rineka Cipta.

Sarwono W., Sarlito. (2006). Psikologi Remaja. Jakarta: PT. Raja Grafindo.

Sobur, Alex. (2003). Psikologi Umum. Bandung: CV Pusaka Setia.

Sukardi, Dewa Ketut. (2008). Pengantar Pelaksanaan Bimbingan dan Konseling Sekolah. Jakarta: PT. Rineka Cipta.

Walgito, Bimo. (2010). Pengantar Psikologi Umum. Yogyakarta: ANDI.

Winkel. W. S dan Hastuti, Sri. (2006). Bimbingan dan Konseling di Institusi Sekolah. Yogyakarta: Media Abadi.

Yusuf, Syamsu. (2012). Jenis Layanan dan Pendukung Kegiatan BK. Bandung: Risqi Press. 